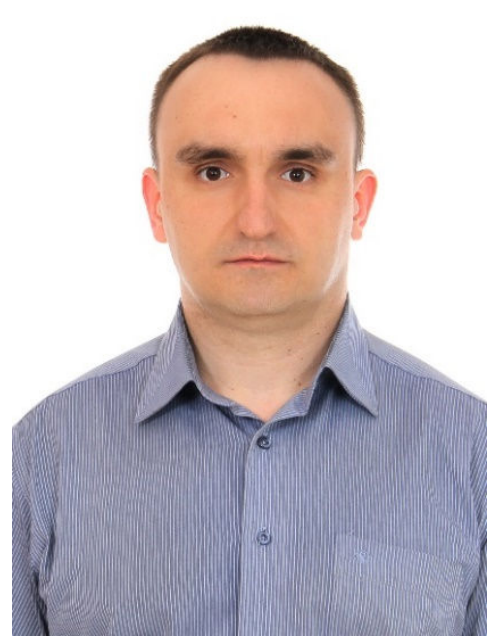

Постановка проблеми. Розвиток й оновлення сучасної національної правової системи невід'ємно пов'язані 3 удосконаленням теоретичного підгрунтя кожної 3 вітчизняних галузей права. Одним із напрямів цього процесу є сфера внутрішньодержавної діяльності щодо виконання та відбування кримінальних покарань i, відповідно, нормативний комплекс, що регулює цю сферу правовідносин у нашій державі. Ключовим напрямом удосконалення теоретичних аспектів національного кримінально-виконавчого права є 3'ясування кореляційної складової груп базових засад, на яких грунтуються такі важливі елементи сучасної кримінально-виконавчої дійсності, як кримінально-виконавча політика та кримінально-виконавче право. Остаточне встановлення співвідношення вказаних принципів сприятиме подальшому коректному розумінню місця та ролі зазначених засад у формуванні кримінально-виконавчої політики та відповідної галузі права, а також визначатиме подальший розвиток згаданих фундаментальних засад.

Аналіз останніх досліджень та публікацій. Питання, пов'язані з визначенням засад кримінально-виконавчого права та політики, досліджувалися в роботах таких науковців, як І. Г. Богатирьов, О.М.Джужа, Ю.В.Кернякевич-Танасійчук, О. Г. Колб, В. В. Кондратішина, О. М. Литвинов, С. С. Назимко, А. Х. Степанюк， В. М. Трубников, П. Л. Фріс, І. С. Яковець та ін.

Метою статті $\epsilon$ визначення належної кореляції засад внутрішньодержавної системи виконання і відбування кримінальних покарань у контексті співвідношення принципів кримінально-виконавчого права та відповідної політики.

Виклад основного матеріалу. Сучасна внутрішньодержавна система виконання i відбування кримінальних покарань $є$ правовим механізмом, ключовими характеристиками (C) Пилипенко Д. О., 2021 
якого є багатокомпонентність елементів його будови та сталий і дієвий зв'язок між ними. До таких елементів, безумовно, належать внутрішньодержавна політика у сфері виконання і відбування покарань та галузь кримінально-виконавчого права. Указані елементи будови вітчизняної кримінально-виконавчої системи є найбільш змістовними та важливими іiі складовими. Кожен 3 них містить «стрижневі компоненти», які відображають сутність як політики, так і права, а також визначають їхні напрями розвитку та співвідношення. Одним із цих компонентів є засади (принципи). Так, О. О. Шкута наголошує, що «для вітчизняної юридичної науки розроблення проблем принципів кримінально-виконавчої політики $\epsilon$ значною мірою новим напрямом наукового пошуку, під час розроблення якого слід враховувати якісно нову парадигму виконання покарань в умовах побудови демократичної та правової держави, наближення вітчизняного кримінально-виконавчого законодавства до міжнародних стандартів» [1, с. 270]. На думку автора, принципи кримінально-виконавчої політики слід розуміти як загальні керівні положення, ідеї, імперативні вимоги, які становлять основу формування та реалізації державної політики у сфері виконання кримінальних покарань, характеризують іï сутність і призначення в суспільстві й мають доктринальне вираження та нормативно-правове закріплення [1, с. 274]. П. Л. Фріс, розглядаючи це питання, указував, що «політика, для того щоб виправдати своє призначення, повинна бути принциповою, мати систему керівних ідей - систему певних принципів» [2, с. 48]. М. М. Яцишин визначає принципи кримінально-виконавчої політики як першооснови ефективної практики виконання покарань. Учений уважає, що до принципів кримінально-виконавчої політики належать: суверенітет, наукова обгрунтованість та незалежність від ідеологічних установок і рішень будь-яких політичних партій і течій; пріоритет загальновизнаних людських цінностей, життя та здоров'я людини; перевага прав людини над державними та суспільними інтересами за умов їхнього гармонійного поєднання; відповідальність держави перед громадянами й суспільством за результати своєї діяльності; розподіл компетенцій між суб'єктами кримінально-виконавчої політики, який виключає можливість монопольного прийняття для кримінальновиконавчої системи рішень будь-якою окремою особою або окремою гілкою влади; системне охоплення всього комплексу проблем кримінально-виконавчої діяльності; інтеграція з іншими галузями соціальної політики держави; повага до загальновизнаних принципів міжнародного права; гуманізм та демократичний характер кримінальновиконавчої діяльності [3, с. 15]. В. М. Трубников тлумачить принципи кримінальновиконавчої політики як основоположні начала (провідні ідеї), що виникають із соціальноекономічної природи суспільного ладу, які закріплені в праві та які визначають спрямованість, характер, підстави й обсяг правового регулювання суспільних відносин. Науковець виокремлює загальнополітичні (загальногалузеві) та специфічні (галузеві) принципи [4, с. 5]. Є. О. Письменський поділяє думку О. О. Шкути та стверджує, що сучасна кримінально-виконавча політика України в контексті діяльності кримінальновиконавчої системи має бути спрямована на реалізацію принципів гуманізму, демократизму, пріоритету загальних прав і свобод людини, забезпечення диференціації виконання покарань та індивідуального особистісного підходу до засуджених у процесі їхнього виправлення і ресоціалізації, раціонального застосування заходів переконання та примусу до засуджених, комплексного й системного (безперервного) впливу на особу засудженого, прогресивної системи виконання покарання та поваги до загальновизнаних принципів міжнародного права. Цими основними засадами мають керуватися суб'єкти, які формують кримінально-виконавчу політику та беруть участь у її реалізації [5, с. 84].

Одним із фундаторів дослідження принципів кримінально-виконавчої політики (виправно-трудової політики на той час. - Д. П.) був I. А. Сперанський, який такими принципами вважав: класовий підхід до виконання покарання; соціалістичний демократизм; суворе дотримання законності під час виконання покарання; соціалістичний гуманізм; поєднання переконання та примусу; можливість виправлення осіб, які вчинили 
злочини; диференційований та індивідуальний підхід до виконання покарання; поєднання виконання покарання із заходами виправно-трудового впливу; провідну роль суспільнокорисної праці у виправленні засуджених [6, с. 10]. Ю. В. Кернякевич-Танасійчук визначає принципи кримінально-виконавчої політики України як систему керівних ідей, засад, що обумовлюють (є основою) формування кримінально-виконавчого законодавства та його застосування у процесі виконання-відбування покарань [7, с. 85]. Крім того, учена класифікує принципи кримінально-виконавчої політики на три групи (загальноправові, міжгалузеві, галузеві) [7, с. 92]. Також авторка пропонує додати до цього переліку додаткову групу принципів окремих інститутів (напрямів) кримінально-виконавчої політики і цю групу, у свою чергу, поділити на дві підгрупи: 1) принципи політики у сфері виконання покарань, пов'язаних з ізоляцією; 2) принципи політики у сфері виконання покарань, не пов'язаних з ізоляцією [7, с. 112]. В. В. Кондратішина зауважує, що принципи кримінально-виконавчої політики України - це теоретично обгрунтовані, сформульовані в чинному законодавстві та застосовувані на практиці основні положення (керівні ідеї тощо), які зумовлені об'єктивними закономірностями реалізації відповідного кримінального покарання та досягнення його мети $[8$, с. 68]. Зазначені позиції науковців свідчать про надання ними провідного значення політиці у кримінально-виконавчій сфері. Змістовна складова поглядів указаних учених є сталою концепцією, за якою діяльність щодо формування та реалізації кримінально-виконавчої політики $\epsilon$ ключовою у функціонуванні всієї системи виконання і відбування кримінальних покарань. Згідно 3 цією концепцією політика має певну перевагу над галуззю права. Так, А. Х. Степанюк наголошує, що кримінально-виконавчу політику як один із напрямів боротьби зі злочинністю варто розуміти як науку про принципи, цілі та завдання діяльності органів й установ виконання покарань та про необхідні для досягнення мети виконання покарання засоби, які мають у розпорядженні адміністрації цих закладів. Також він зазначає, що принципи кримінально-виконавчої політики як науки, тобто наукові ідеї, які формулюють учені й пропонують застосовувати їх як правові принципи, більш змістовні, ніж принципи права, тому що не всі принципи кримінально-виконавчої політики можуть стати правовим явищем. Доктринальні принципи кримінально-виконавчої політики можуть трансформуватися у принципи кримінально-виконавчого права, набути їхньої форми тільки після того, як їх ухвалить законодавець [9, с. 254]. Отже, на думку автора, принципи кримінально-виконавчої політики - це наукові ідеї, що не збігаються 3 принципами кримінально-виконавчого права, тому між ними не можна ставити «знак рівності» [9, c. 255].

Досліджуючи це питання, Ю. В. Шинкарьов стверджує, що принципи кримінальновиконавчого права є керівними, базовими ідеями, настановами, які визначають основні напрями розвитку цієї галузі права. Ці принципи трансформовані із засад кримінальновиконавчої політики (які $є$ первинними щодо принципів кримінально-виконавчого права) i спрямовані на забезпечення відповідності правового регулювання виконання та відбування кримінальних покарань основним напрямам кримінально-виконавчої політики. До того ж автор указує, що принципи кримінально-виконавчого права не рівнозначні принципам кримінально-виконавчого законодавства, які визначають не провідні напрями розвитку галузі права (кримінально-виконавчого), а тільки регламентують особливості розвитку законодавства цієї галузі та основні загальні вимоги до виконання кримінальних покарань. Крім того, принципи кримінально-виконавчого права, на відміну від принципів законодавства, не мають нормативного вираження, а є лише теоретичними положеннями [10, с. 496]. В. М. Трубников поділяє думку щодо співвідношення принципів кримінальновиконавчої політики та права. Учений наголошує, що правильною є позиція, згідно з якою коло основних положень (начал), що розглядаються як принципи кримінально-виконавчої політики, ширше за коло положень, які стосуються принципів кримінально-виконавчого права, оскільки до перших належать найзагальніші положення [4, с. 8]. П. Л. Фріс, 
аналізуючи співвідношення принципів політики та права у кримінальному праві, зазначав, що воно виражається в тому, що перші з них: а) закріплюються не тільки в нормах права, а й в інших документах; б) визначають як характер кримінального законодавства, так і практику його застосування; в) належать до «утворюючих» («складових») принципів кримінального права. За способом вираження, характером і змістом принципи кримінально-правової політики відрізняються від принципів кримінального права, і в цьому значенні саме вони є основою для формування останніх, а не навпаки [2, с. 51]. Ю. В. Кернякевич-Танасійчук, досліджуючи вказане питання, робить висновок щодо співвідношення між принципами кримінально-виконавчого права i принципами кримінально-виконавчої політики. По-перше, принципи кримінально-виконавчої політики $\epsilon$ первинними порівняно з принципами кримінально-виконавчого права, оскільки останні $\epsilon$ формою (зовнішньою) відображення принципів кримінально-виконавчої політики. Подруге, поняття «принципи кримінально-виконавчої політики» є більш змістовним, ніж поняття «принципи кримінально-виконавчого права», оскільки не всі принципи політики об'єктивовано в нормативно-правових актах як основне джерело кримінально-виконавчого права та кримінально-виконавчої політики. Принципи кримінально-виконавчої політики може бути передбачено й іншими документами [7, с. 84]. Також вона зауважує, що можна виділити за аналогією і третю відмінність між принципами кримінально-виконавчої політики та кримінально-виконавчого права, а саме: принципи кримінально-виконавчої політики визначають не лише характер кримінально-виконавчого законодавства, а й впливають на процес виконання-відбування покарань [7, с. 85]. Г. С. Семаков та А. П. Гель стверджують, що кримінально-виконавча політика здійснюється за допомогою таких засобів, як кримінально-виконавче право, діяльність спеціальних державних органів, участь громадськості у виправленні засуджених, заходів педагогічного та соціальнопсихологічного характеру. Головною формою вираження та закріплення кримінальновиконавчої політики є кримінально-виконавче право. Це пояснюється тим, що політика і право тісно взаємопов'язані, оскільки право створюється політичною організацією суспільства - державою. Первинність ролі кримінально-виконавчої політики щодо кримінально-виконавчого права, на думку авторів, полягає у тому, що політика визначає основні вимоги до виконання та відбування кримінальних покарань, змісту, формування, розвитку й застосування норм кримінально-виконавчого права. Згідно 3 принципами кримінально-виконавчої політики кримінально-виконавче право регулює суспільні відносини, що виникають у процесі виконання покарань $[11$, с. 5]. Слід зазначити, що позиція стосовно пріоритетності принципів кримінально-виконавчої політики над правовими $є$ домінантною серед науковців, які досліджували та досліджують указане питання.

Однак деякі вчені, які у своїх роботах розглядали окреслену проблематику, мають протилежну точку зору щодо співвідношення принципів кримінально-виконавчого права та політики. Так, М. О. Стручков наголошував, що коли мова йде про принципи права чи галузі права, зокрема виправно-трудового права, у них відображаються і принципи політики, і принципи діяльності відповідних установ й органів [12, с. 80]. В. В. Мальцев теж уважає, що принципи політики є другорядними, їхня роль полягає в тому, щоб точніше і повніше відображати зміст принципів права в законодавстві [13, с. 275]. Крім того, науковці поділяють думку щодо визнання рівноцінності зазначених різновидів принципів. 3 цього приводу В. О. Уткін зауважує, що принципами кримінальновиконавчого (виправно-трудового) права $\epsilon$ вихідні положення, що одночасно $\epsilon$ i принципами кримінально-виконавчої політики, і принципами діяльності кримінальновиконавчої системи $[14$, с. 56].

Так, дослідники, які визнають провідний статус принципів політики відносно кримінально-виконавчого права, обгрунтовують свою точку зору з різних позицій. Ці позиції, безумовно, містять переконливі аргументи стосовно вагомості політики та їі 
впливу на кримінально-виконавче право. Здебільшого такі аргументи зумовлено «локальними» уявленнями про багатоаспектність кримінально-виконавчої політики та традиційних переконань щодо «вищого призначення» політики порівняно з галуззю права. Проте, на наш погляд, такі переконання існували й раніше, їх сформовано та прийнято суспільством як аксіоматичну модель чинної будови внутрішньодержавного життя. На підтвердження власної позиції вбачаємо доцільним розглянути вплив політики й права на суспільство і процеси, які в ньому відбуваються. У сучасній літературі виникає питання: «Право і політика: що є впливовішим у державі?» Відповідь така: «На жаль, політика, тому що наша держава не стала поки що правовою» $[15$, c. 60$]$. За часів радянського тоталітаризму на території сучасної України розповсюдженою була точка зору щодо безумовної, керівної ролі державної політики над усіма сферами внутрішнього життя держави та, зокрема, правової системи. Ю. А. Агешин ще за радянських часів стосовно цього питання вказував, що політика і право у своїй взаємодії відіграють неоднакову роль. Політика $\epsilon$ більш важливою та активною частиною суспільної надбудови. Політика, знайшовши своє втілення у праві, вже не лише самостійно, а й за допомогою правових засобів має вплив на матеріальне життя суспільства [16, с. 57; 17, с. 118]. В. М. Чхіквадзе, дотримуючись аналогічної думки, зазначав, що політика - це внутрішній двигун права, який має вирішальний вплив на його розвиток. «Право ніщо без політики», - робить висновок автор $[18$, с. 53]. Отже, політика як елемент суспільної надбудови, за твердженням багатьох науковців, має вирішальне значення для формування та реалізації як внутрішньодержавних, так і зовнішньодержавних процесів. Із цим важко сперечатися, якщо поняття «політика» розглядати в широкому розумінні, тобто як визначальне явище для існування держави загалом. До того ж в умовах сьогодення більшість членів суспільства розраховує на «сильну» політику та відповідних політичних діячів як на гарантів стабільності не лише в державі, а й у світі в цілому. Чинник «сильної» міжнародної політики на цьому історичному етапі $є$ дуже важливим, ураховуючи сучасні загрози національній безпеці, які існують із 2014 року. Проте цей чинник важко сприйняти як об'єктивний у разі визначення його як одного 3 напрямів внутрішньодержавної політики, зокрема у сфері виконання і відбування кримінальних покарань. За цих умов відокремлення права від політики та надання останній пріоритетного значення визначає закономірний шлях до авторитаризму та тоталітаризму. Подібна ситуація вже траплялася в нашій країні під час перебування у складі СРСР. Одним із наслідків такої внутрішньодержавної політики було нехтування правами людини, особливо у кримінально-виконавчій сфері. Із моменту проголошення незалежності в 1991 році наша держава поступово позбавляється наслідків такої політики, зокрема у правовій сфері, та обирає напрям цивілізованої та загальновизнаної світової парадигми щодо пріоритетності прав людини. Саме така парадигма набуває особливого значення, у якій внутрішньодержавний політичний механізм конфліктує зі сферою природних прав людини, серед яких - право на свободу та особисту недоторканність. Це право є елементом комплексу природно-правових засад, які $\epsilon$ початковим етапом виникнення та функціонування сучасної демократичної держави. Саме ці засади визначають діяльність держави та іï політичну сферу, а не навпаки. Тому безапеляційне твердження окремих науковців щодо пріоритетності засад внутрішньодержавної політики у сфері виконання i відбування кримінальних покарань над принципами кримінально-виконавчого права не $\epsilon$ беззаперечним. Крім того, позицію зазначених учених зумовлено ототожненням засад кримінально-виконавчого права та законодавства. Така «співмірність» указаних принципів не відповідає їхній сутності. Слушною з цього приводу є позиція Конституційного Суду України, який наголошує, що згідно з частиною першою ст. 8 Конституції України в Україні визнається і діє принцип верховенства права. Верховенство права - це панування права в суспільстві. Верховенство права вимагає від держави його втілення у правотворчу та правозастосовну діяльність, зокрема в закони, зміст яких повинен передбачати 
передусім ідеї соціальної справедливості, свободи, рівності тощо. Одним із проявів верховенства права $\epsilon$ те, що право не обмежується лише законодавством як однією 3 його форм, а включає також інші соціальні регулятори, зокрема норми моралі, традиції, звичаї тощо, які легітимовані суспільством і спричинені історично досягнутим рівнем розвитку суспільства. Усі ці елементи права об'єднуються якістю, що відповідає ідеології справедливості, ідеї права, яку значною мірою відображено в Конституції України. Таке розуміння права не дає підстав для його ототожнення із законом, який іноді може бути й несправедливим, у тому числі обмежувати свободу та рівність особи [19].

Висновки. Внутрішньодержавна система виконання i відбування покарань характеризується внутрішньою змістовністю елементів, визначення взаємозв'язку та взаємозалежності яких відіграє ключову роль у функціонуванні самої системи. Такими елементами $\epsilon$ внутрішньодержавна кримінально-виконавча політика та кримінальновиконавче право. Важливим аспектом зіставлення цих елементів $\epsilon$ встановлення кореляційних зв'язків між засадами політики та права. Домінантна в теорії кримінальновиконавчого права позиція щодо провідної ролі та пріоритетності принципів політики над засадами кримінально-виконавчого права $\epsilon$ наслідком розповсюдження серед науковців догматичних положень позитивістської концепції походження права. Проте значний інтерес до цієї концепції неодмінно негативно впливатиме на поступове зменшення ролі природно-правової концепції як фундаментального явища, що визначає будову правових систем у сучасних демократичних державах, до яких прагне приєднатися й Україна. Тому в умовах євроінтеграційного та, відповідно, цивілізаційного шляху нашої держави кореляційний зв'язок між елементами внутрішньодержавної системи у сфері виконання i відбування покарань має відбуватися 3 необхідним наданням пріоритетності саме принципам права над засадами інших елементів цієї системи, ураховуючи кримінальновиконавчу політику. За таких умов комплекс засад внутрішньодержавної системи виконання i відбування покарань формує інтегральний, внутрішньосистемний, кореляційний зв'язок між ними 3 обов'язковою i провідною роллю принципів кримінально-виконавчого права в цій системі.

\section{Список використаних джерел}

1. Шкута О. О. Теоретико-прикладні засади функціонування кримінально-виконавчої системи України : дис. ... д-ра юрид. наук. Запоріжжя, 2017. 480 с.

2. Фріс П. Л.Кримінально-правова політика Української держави: теоретичні, історичні та правові проблеми. Київ : Атіка, 2005. 332 с.

3. Яцишин М. М. Історико-правові засади кримінально-виконавчої політики України. Луцьк : Волинський нац. ун-т ім. Лесі Українки, 2010. 440 с.

4. Трубников В. М. Кримінально-виконавче право України. Харків : Право, 2001. 379 с.

5. Шкута О. О. Концептуальні принципи пенітенціарної політики України. Підприємництвво, господарство і право. № 5. 2016. С. 81-85.

6. Сперанский И. А. Основные вопросы советского исправительно-трудового права: курс лекцій. Москва : Академия МВД СССР, 1976. 122 с.

7. Кернякевич-Танасійчук Ю. В. Кримінально-виконавча політика України : дис. ... д-ра юрид. наук. Івано-Франківськ, 2019. 535 с.

8. Кондратішина В. В. Кримінально-виконавча політика України: формування та реалізація : дис. .... канд. юрид. наук. Львів, 2009. 275 с.

9. Степанюк А. Х. Актуальні проблеми виконання покарань (сутність та принципи кримінально-виконавчої діяльності: теоретико-правове дослідження) : дис.... д-ра юрид. наук : 12.00.08. Харків, 2002. 398 с.

10. Шинкарьов Ю. В. Щодо визначення принципів кримінально-виконавчого права та законодавства. Розвиток державності та права в Україні: реалії та перспективи: зб. наук. праць матер. 1-ї Міжнар. наук.-практ. конф. (м. Сімферополь, 24 квіт. 2009 р.). Сімферополь : Крим. навч. пед. держ. видав., 2009. Ч. 1. С. 495-497. $122 \mathrm{c}$.

11. Семаков Г. С., Гель А. П. Кримінально-виконавче право України : курс лекцій. Київ, 2000. 
Правовий часопис Аонбасу № 4 (77) 2021

12. Стручков Н. А. Курс исправительно-трудового права. Проблемы Общей части. М. : Юрид. лит., 1984. 240 с.

13. Мальцев В.В. Принципы уголовного права и их реализация в правоприменительной деятельности. СПб., 2004. 692 с.

14. Уткин В. А. Курс лекций по УИП. Общая часть. Томск, 1995. 94 с.

15. Мохонько А. В. Право та політика як регулятори суспільних відносин. Часопис Київського університету права. № 1. 2011. С. 59-62.

16. Агешин Ю. А. Политика, право, мораль. М. : Юрид. лит., 1982. 160 с.

17. Вітвіцький С. С. Методологічні засади дослідження контролю в Україні. Бюлетень Міністерства юстиції України. № 6. 2014. С. 116-122.

18. Чхиквадзе В. М. Государство, демократия, законность. М. : Юрид. лит., 1967. 503 с.

19. Верховенство права. Конституційний Суд України. URL: https://ccu.gov.ua/storinka-knygy/34verhovenstvo-prava.

20. Назимко Є. С., Данилевський А. О., Данилевська Ю. О., Гранкіна В. I. Кримінальновиконавче право України : навчальний посібник. Київ : Дакор, 2020. 210 с.

\section{References}

1. Shkuta, O. O. (2017). Teoretyko-prykladni zasady funktsionuvannia kryminalno-vykonavchoi systemy Ukrainy [Theoretical and Applied Principles of Functioning of the Criminal Executive System of Ukraine] : dys. ... d-ra yuryd. nauk. Zaporizhzhia. 480 s. [in Ukrainian].

2. Fris, P. L. (2005). Kryminalno-pravova polityka Ukrainskoi derzhavy: teoretychni, istorychni ta pravovi problemy [Criminal law policy of the Ukrainian state: theoretical, historical and legal problems]. Kyiv : Atika. 332 s. [in Ukrainian].

3. Yatsyshyn, M. M. (2010). Istoryko-pravovi zasady kryminalno-vykonavchoi polityky Ukrainy [Historical and legal principles of criminal executive policy of Ukraine]. Lutsk: Volynskyi nats. un-t im. Lesi Ukrainky. 440 s. [in Ukrainian].

4. Trubnykov, V. M. (2001). Kryminalno-vykonavche pravo Ukrainy [Criminal executive law of Ukraine]. Kharkiv : Pravo. 379 s. [in Ukrainian].

5. Shkuta, O. O. (2016). Kontseptualni pryntsypy penitentsiarnoi polityky Ukrainy [Conceptual principles of Penitentiary Policy of Ukraine]. Pidpryiemnytstvo, hospodarstvo i pravo. № 5. S. 81-85 [in Ukrainian].

6. Speranskij, I. A. (1976). Osnovnye voprosy sovetskogo ispravitel'no-trudovogo prava : kurs lekcij [The main issues of Soviet correctional labor law: a course of lectures]. Moskva: Akademiya MVD SSSR. 122 s. [in Russian].

7. Kerniakevych-Tanasiichuk, Yu. V. (2019). Kryminalno-vykonavcha polityka Ukrainy [Criminal executive policy of Ukraine] : dys. ... d-ra yuryd. nauk. Ivano-Frankivsk. $535 \mathrm{~s}$. [in Ukrainian].

8. Kondratishyna, V. V. (2009). Kryminalno-vykonavcha polityka Ukrainy: formuvannia ta realizatsiia [Criminal executive policy of Ukraine: Formation and implementation] : dys. ... kand. yuryd. nauk. Lviv. 275 s. [in Ukrainian].

9. Stepaniuk, A. Kh. (2002). Aktualni problemy vykonannia pokaran (sutnist ta pryntsypy kryminalno-vykonavchoi diialnosti: teoretyko-pravove doslidzhennia) [Actual problems of punishment (essence and principles of criminal executive activity: theoretical legal research)] : dys. ... d-ra yuryd. nauk : 12.00.08. Kharkiv. 398 s. [in Ukrainian].

10. Shynkarov, Yu. V. (2009). Shchodo vyznachennia pryntsypiv kryminalno-vykonavchoho prava ta zakonodavstva [Regarding the definition of the principles of criminal executive law and legislation]. Rozvytok derzhavnosti ta prava v Ukraini: realii ta perspektyvy : zb. nauk. prats mater. 1-yi Mizhnar. nauk.-prakt. konf. (m. Simferopol, 24 kvit. 2009 r.). Simferopol : Krym.navch.ped.derzh.vydav. Ch. 1. S. 495-497 [in Ukrainian].

11. Semakov, H. S., Hel, A. P. (2000). Kryminalno-vykonavche pravo Ukrainy : kurs lektsii [Criminalexecutive law of Ukraine : Course of lectures]. Kyiv. 122 s. [in Ukrainian].

12. Struchkov, N. A. (1984). Kurs ispravitel'no-trudovogo prava. Problemy Obshchej chasti [Course of correctional labor law. Problems of the General part]. M. : YUrid. lit. 240 s. [in Russian].

13. Mal'cev, V. V. (2004). Principy ugolovnogo prava $i$ ih realizaciya $v$ pravoprimenitel'noj deyatel'nosti [Principles of criminal law and their implementation in law enforcement]. SPb. $692 \mathrm{~s}$. [in Russian].

14. Utkin, V. A. (1995). Kurs lekcij po UIP. Obshchaya chast' [Course of lectures on UIP. A common part]. Tomsk. 94 s. [in Russian].

15. Mokhonko, A. V. (2011). Pravo ta polityka yak rehuliatory suspilnykh vidnosyn [Law and politics as regulators of social relations]. Chasopys Kyivskoho universytetu prava. № 1. S. 59-62 [in Ukrainian].

16. Ageshin, YU. A. (1982). Politika, pravo, moral' [Politics, law, morality]. Moscow: YUrid. lit. 160 s. [in Russian]. 
17. Vitvitskyi, S. S. (2014). Metodolohichni zasady doslidzhennia kontroliu v Ukraini [Methodological principles of investigation in Ukraine]. Biuleten Ministerstva yustytsii Ukrainy. № 6. S. 116-122 [in Ukrainian].

18. Chkhikvadze, V. M. (1967). Gosudarstvo, demokratiya, zakonnost' [State, democracy, legality]. Moscow : YUrid. lit. 503 s. [in Russian].

19. Verkhovenstvo prava. Konstytutsiinyi Sud Ukrainy [Rule of Law. Constitutional Court of Ukraine]. URL: https://ccu.gov.ua/storinka-knygy/34-verhovenstvo-prava [in Ukrainian].

20. Nazymko, Ye. S., Danylevskyi, A. O., Danylevska, Yu. O., Hrankina, V. I. (2020). Kryminalnovykonavche pravo Ukrainy: navchalnyi posibnyk [Criminal executive law of Ukraine: Tutorial.]. Kyiv: Dakor. 210 s. [in Ukrainian].

\author{
Pylypenko Dmytro, \\ $\mathrm{PhD}$ in Law \\ (Donetsk State University of Internal Affairs, Kryvyi Rih) \\ ORCID: https://orcid.org/0000-0003-1299-6178
}

\title{
REGARDING A CORRELATION OF THE PRINCIPLES OF THE DOMESTIC SYSTEM OF EXECUTION AND SERVING OF CRIMINAL PUNISHMENTS
}

The article is devoted to defining the correlations between the principles of the domestic system of execution and serving of criminal punishments. The issue focuses on defining the links between the principles of criminal enforcement policy and criminal executive law. The article analyzes the theoretical positions of scientists who study this issue. The vast majority of scholars' positions are focused on the dominant position of domestic policy in the field of execution and serving sentences as a key element of the entire penitentiary system. Given this, the correlation between the principles of the elements of the system of execution and serving sentences is determined by giving priority to the principles of domestic policy over the principles of other elements, taking into account the direct criminal law. As can be seen, this theoretical state is due to the leading importance of the positivist concept of the origin of law, which is very common among domestic scholars. The article draws attention to the inevitable shortcomings of which leads to excessive attention to this concept. One of these shortcomings is the gradual reduction of the role of the natural law concept in society and, as a consequence, the narrowing of human rights and freedoms. The paper emphasizes that this aspect is unacceptable for a modern, democratic state in which the indisputable axiom is the proclamation of the leading role of human rights and freedoms in society and the state. Thus, under these conditions, the natural law concept should play a key role in building modern legal systems. Thus, the article defines the result according to which the correlation of the principles of the domestic system of execution and serving criminal sentences should take place with priority given to the principles of criminal executive law over all elements, taking into account the principles of domestic policy in the execution and serving of criminal sentences.

Key words: system of execution and serving of punishments; criminal-executive policy; criminal-executive law; principles of execution and serving of punishments; correlation.

Надіслано до редколегії 13.09.2021 Рекомендовано до публікації 20.09.2021 